\title{
PENGARUH SIKAP DAN MOTIVASI TERHADAP MINAT BERWIRAUSAHA MAHASISWA
}

\author{
Venny Adhita Octaviani \\ Fakultas Ilmu Sosial dan Ilmu Politik Universitas Kapuas Sintang \\ Email:adhitavenny@gmail.com \\ Universitas Kapuas Sintang, Jln. Y.C.Oevang Oeray No.92 Sintang, Kalimantan Barat
}

\begin{abstract}
Abstrak: Penelitian ini bertujuan untuk mengetahui dan menganalisis pengaruh sikap dan motivasi terhadap minat berwirausaha mahasiswa Prodi Administrasi Bisnis Fakultas Ilmu Sosial dan Ilmu Politik Universitas Kapuas Sintang. Metode penelitian yang digunakan adalah deskriptif kuantitatif dengan sampel mahasiswa Prodi Administrasi Bisnis Fakultas Ilmu Sosial dan Ilmu Politik Universitas Kapuas Sintang yang berjumlah 61 mahasiswa responden. Hasil penelitian menunjukkan bahwa 1) Sikap tidak berpengaruh signifikan terhadap minat berwirausaha mahasiswa Prodi Ilmu Administrasi Bisnis Fisip Unka, yang ditunjukkan dengan tingkat signifikansi t hitung $>0,05(0,121>0,05)$. 2) Motivasi berpengaruh signifikan terhadap minat berwirausaha mahasiswa Prodi Ilmu Administrasi Bisnis Fisip Unka yang ditunjukkan dengan tingkat signifikansi t hitung lebih kecil dari $0,05(0,000<0,05)$. Hasil uji koefisien determinasi menunjukkan bahwa sebesar 41,4\% variabel minat mahasiswa akan dipengaruhi oleh variabel bebasnya, yaitu sikap dan motivasi, sedangkan sisanya 58,6\% variabel minat mahasiswa akan dipengaruhi oleh variabel-variabel yang lain yang tidak dibahas dalam penelitian ini.
\end{abstract}

Kata Kunci : Pengaruh Sikap dan Motivasi

Pengangguran merupakan salah satu permasalahan nasional yang harus dituntaskan oleh pemerintah. Pengangguran merupakan suatu akibat dari keadaan dimana jumlah tenaga kerja lebih lapangan pekerjaan yang disediakan. Salah satu penyebab adanya pengangguran adalah jumlah penduduk yang dari tahun ke tahun meningkat namun tidak dibarengi dengan peningkatan atau perluasan lapangan pekerjaan.Masalah pengangguran tidak hanya dapat merugikan dalam segi ekonominya saja, namun juga dapat berpengaruh dalam segi politik, keamanan, dan social sehingga mengganggu pertumbuhan dan pembangunan. Dan, jangka panjang nya akan berakibat menurunnya GNP dan pendapatan perkapita suatu negara.

Menurut CIA World Factbook 2004Indonesia merupakan salah satu negara yang memiliki jumlah penduduk terbanyak ke empat di dunia setelah Tiongkok, India dan Amerika. Badan Pusat Statistik juga menyebutkan bahwa Indonesia memiliki penduduk miskin sebanyak 25.14 juta jiwa per 1 Maret 2019. Ini menunjukkan bahwa pemerintah Indonesia khususnya, harus dapat menemukan strategi yang tepat dalam menyelesaikan atau mengurangi permasalahan tersebut.Untuk mengurangi angka pengangguran di Indonesia maka pemerintah juga harus turun tangan dengan cara mengeluarkan kebijakankebijakan yang dapat menciptakan lapangan pekerjaan baru, maupun dengan cara-cara lainnya antara lain agar masyarakat mau berwirausaha.
Dan untuk menjalankan kebijakan-kebijakan tersebut, pemerintah juga harus memberikan pelatihan, penyuluhan dan pembinaan kepada masyarakat untuk bisa mengembangkan kemampuannya. Selain pemerintah yang membuat kebijakan, masyarakat juga harus berpartisipasi mendukung upaya pengurangan pengangguran yang ada di Indonesia.

Perguruan Tinggi merupakan salah satu wadah yang dapat membantu pemerintah dalam mengatasi masalah pengangguran dengan cara memberikan edukasi kepada mahasiswa melalui mata kuliah kewirausahaan. Keberadaan mahasiswa saat ini bukan hanya dituntut untuk bisa menjadi seorang akademisi saja, namun lebih dari itu mahasiswa juga dituntut untuk bisa menjadi seorang wirausahawan. Oleh sebab itulah perlu adanya dukungan dari Perguruan Tinggi untuk bisa menciptakan lulusan mahasiswa yang kreatif, imajinatif, dan berani mengambil resiko. Program dan modul kewirausahaan dapat memiliki berbagai tujuan, seperti: Pengembangan Kewirausahaan di kalangan siswa (meningkatkan kesadaran dan motivasi); Mengembangkan kemampuan kewirausahaan untuk mengidentifikasi dan memanfaatkan peluang;Pelatihan keterampilan yang dibutuhkan untuk memulai dan mengelola pertumbuhan bisnis.

Dengan adanya program dan modul kewirausahaan tersebut diharapkan dapat mempengaruhi minat mahasiswa agar kelak mau berwirausaha. Peranan prodi dalam memotivasi 
mahasiswa, sikap dan menumbuhkanminat sangat penting dalam menumbuhkan jumlah wirausaha. Peran perguruan tinggidalam mengembangkan minat berwirausaha dan menggali beberapa faktor yangberpengaruh pada perilaku berwirausaha telah digali oleh beberapa peneliti (Autio, Keeley, Klofsten, \& Ulfstedt, 1997; Budiati, Yani, \& Universari, 2012). Penelitian-penelitian tersebut menjelaskan bahwa minat kewirausahaan yangdapat diarahkan melalui pendidikan kewirausahaan dipengaruhi oleh sikap danminat terhadap kewirausahaan. Hasil penelitian ini diharapkan menjadipendukung model kewirausahaan untuk memotivasi mahasiswa, sehinggamendorong minat mahasiswa menjalankan usahanya tanpa ada keraguan ataumalu dalam menjalankan usaha dimulai dari awal walaupun modal kecil.

\section{Landasan Teori Kewirausahaan}

Secara etimologi, kewirausahaan berasal dari kata wira dan usaha. Wira berarti peluang, pahlawan, manusia unggul, teladan, berbudi luhur, gagah berani, dan berwatak agung. Sedangkan menurut Kamus Besar Bahasa Indonesia, wirausaha adalah orang yang pandai atau berbakat mengenali produk baru, menentukan cara produksi baru, menyusun operasi untuk mengadakan produk baru, mengatur permodalan operasinya, serta memasarkannya.

Zimmere (dalam Suryana, 2014:11) kewirausahaan adalah penerapan kreativitas dan inovasi untuk memecahkan masalah dan upaya memanfaatkan peluang yang dihadapi setiap hari. Menurut Gitosardjono (2013:206) ada enam hakikat kewirausahaan yaitu:

1. Kewirausahaan adalah kemampuan menciptakan sesuatu yang baru dan berbeda.

2. Kewirausahaan adalah suatu nilai yang diwujudkan dalam perilaku yang dijadikan sumber daya, tenaga penggerak,tujuan, strategi, proses dan hasil bisnis.

3. Kewirausahaan adalah suatu proses dalam mengerjakan sesuatu kreatif dan inovatif yang bermanfaat dalam memberikan nilai lebih.

4. Kewirausahaan adalah suatu proses penerapan kreatifitas dan keinovasian dalam memecahkan persoalan dan menemukan peluang untuk memperbaiki, serta mengembangkan kehidupan usaha.

5. Kewirausahaan adalah suatu nilai yang dibutuhkan untuk memulai sebuah usaha dan mengembangkan usaha yang dinyakini akan sukses.
6. Kewirausahaan adalah usaha menciptakan nilai tambah dengan jalan mengkombinasikan semua sumber daya secara kreatif dan inovatif untuk memenangkan persaingan.

Berdasarkan definisi diatas kewirausahaan dapat didefinisikan sebagai suatu kemampuan kreatif dan inovatif yang dijadikan kiat, dasar, sumber daya, proses, dan perjuangan untukmenciptakan nilai tambah barang dan jasa yang dilakukan dengan keberanian menghadapi risiko.

\section{Minat Berwirausaha}

Menurut Slameto (2003:59) minat adalah kecenderungan yang tetap untuk memperhatikan dan mengenang beberapa kegiatan. Kegiatan yang dinikmati seseorang, diperhatikan terus-menerus yang disertai dengan rasa senang. Jadi berbeda dengan perhatian, karena perhatian sifatnya sementara dan belum tentu diikuti dengan perasaan senang, sedangkan minat selalu dikuti dengan perasaan senang dan situ diperoleh kepuasan.Menurut Sabri (2007:84) yang dimaksud dengan minat (interes) adalah suatu kecenderungan untuk selalu memperhatikan dan mengingat sesuatu secara terus-menerus.

Berdasarkan pendapat di atas maka dapat disimpulkan bahwa minat adalah rasa ketertarikan untuk selalu memperhatikan dan mengingat sesuatu secara terus menerus dan disertai dengan perasaan senang.

Penelitian Subandono (2007: 18), minat wirausaha adalah kecenderungan hati dalam diri subjek untuk tertarik menciptakan suatu usaha yang kemudian mengorganisir, mengatur, menanggung risiko dan mengembangkan usahayang diciptakannya tersebut. Minat wirausaha berasal dari dalam diri seseorang untuk menciptakan sebuah bidang usaha.

Menurut Santoso (2009) minat berwirausaha adalah keinginan, ketertarikan serta kesediaan untuk bekerja keras atau berkemauan keras untuk berdikari atau berusaha memenuhi kebutuhan hidupnya tanpa merasa takut dengan resiko yang akan terjadi, serta senantiasa belajar dari kegagalan yang dialami.

Berdasarkan definisi di atas, maka yang dimaksud dengan minat wirausaha adalah keinginan, ketertarikan serta kesediaan untuk bekerja keras atau berkemauan keras dengan adanya pemusatan perhatian untuk berusaha memenuhi kebutuhan hidupnya tanpa merasa takut akan resiko yang akan 
dihadapi, senantiasa belajar dari kegagalan yang dialami, serta mengembangkan usaha yang diciptakannya. Minat wirausaha tersebut tidak hanya keinginan dari dalam diri saja tetapi harus melihat ke depan dalam potensi mendirikan usaha.

Ada beberapa faktor yang dapat mempengaruhi minat mahasiswa untuk wirausaha menurut Djaali (2008:113), yakni:

1. Kemauan. Kemauan adalah suatu kegiatan yang menyebabkan seseorang mampu untukmelakukan tindakan dalam mencapai tujuan tertentu. Dengan adanya kemauan seseorang untuk mencoba berwirausaha merupakan suatu hal yang baik.

2. Ketertarikan. Ketertarikan adalah perasaan senang, terpikat, menaruh minat kepada sesuatu. Saat ada ketertarikan dari diri seseorang maka ada daya juang untuk meraih yang ingin dicapai. Dalam hal ini adalah ketertarikan untuk mau berwirausaha, maka mahasiswa tersebut mempunyai minat untuk berwirausaha.

3. Lingkungan Keluarga. Berkaitan dengan lingkungan keluarga, maka peran keluarga sangat penting dalam menumbuhkan minat anak. Orang tua merupakan pendidik pertama dan sebagai tumpuan dalam bimbingan kasih sayang yang utama. Maka orang tualah yang banyak memberikan pengaruh dan warna kepribadian terhadap seorang anak. Dengan demikian mengingat pentingnya pendidikan di lingkungan keluarga, maka pengaruh di lingkungan keluarga terhadap anak dapat mempengaruhi apa yang diminati oleh anak.

4. Lingkungan Pendidikan. Pendidikan di sekolah menjadi tanggung jawab guru. Jadi pada dasarnya yang berpengaruh terhadap perkembangan mahasiswa yaitu proses pendidikan di sekolah sebagai bekal untuk diterapkan dalam kehidupan di lingkungan masyarakat. Seorang guru dalam proses pendidikan juga dapat memberikan motivasi dan dorongan kepada mahasiswa dalam menumbuhkan minatnya.

Minat pada hakekatnya merupakan sebab akibat dari pada pengalaman, minat berkembang sebagai hasil dari pada sesuatu kegiatan yang akan menjadi sebab yang akan dipakai lagi dalam kegiatan yang sama. Menurut L. D Crow (dalam Kristsada, 2010: 19-20), menyebutkan faktor yang mempengaruhi minat: The factor inner urge; adalah rangsangan yang datang dari lingkungan atau ruang lingkup yang sesuai dengan keinginan atau kebutuhan seseorang akan mudah menimbulkan minat.The factor of social motive; adalah minat seseorang terhadap obyek atau sesuatu hal, disamping hal dipengaruhi oleh faktor dari dalam diri manusia juga dipengaruhi oleh motif sosial.Emotional factor adalah faktor perasaan dan emosi mempunyai pengaruh terhadap obyek misal perjalanan sukses yang dipakai individu dalam suatu kegiatan tertentu dapat membangkitkan perasaan senang dan dapat menambah semangat atau kuatnya minat dalam kegiatan tersebut.

\section{Teori Sikap}

Sikap berasal dari kata "aptus" yang berarti dalam keadaan sehat dan siap melakukan aksi/tindakan atau dapat dianalogikan dengan keadaan seorang gladiator dalam arena laga yang siap menghadapi singa sebagai lawannya dalam pertarungan. Secara harfiah, sikap dipandang sebagai kesiapan raga yang dapat diamati. Menurut Sarwono (2009:201) sikap (attitude) adalah istilah yang mencerminkan rasa senang, tidak senang, atau perasaan biasa-biasa saja (netral) dari seseorang terhadap sesuatu. Sesuatu itu bisa benda, kejadian, situasi, orang-orang atau kelompok, kalau yang timbul terhadap sesuatu itu adalah perasaan senang, maka disebut sikap positif. Sedangkan perasaan tidak senang disebut sikap negatif. Kalau tidak timbul perasaan apa-apa berarti sikapnya netral.

Sikap menurut Djaali (2008:114) adalah kecenderungan untuk bertindak berkenaan dengan objek tertentu.Berdasarkan pendapat-pendapat tersebut maka dapat disimpulkan bahwa sikap adalah keadaan diri dalam manusia yang menggerakkan untuk bertindak atau berbuat dalam kegiatan tertentu dengan perasaan tertentu di dalam menanggapi objek situasi atau kondisi di lingkungan sekitarnya.

Menurut Zimmerer, dkk (2008) karakteristik sikap kewirausahaan meliputi :

1. Commmitment and determination, yaitu wirausahawan harus mempunyai komitmen dan tekad untuk memberikan perhatian penuh terhadap usaha yang ia jalani, sikap setengah hati akan membuat mereka mudah goyah dan kemungkinan gagal lebih besar.

2. Desire for responsibility, yaitu memiliki rasa tanggung jawab atas usaha-usaha yang dilakukannya. Wirausahan harus mempunyai rasa tanggung jawab yang tinggi atas usaha apa yang sudah dijalankan.

3. Opportunity obsesession, yaitu selalu berambisi untuk mencari peluang. Wirausahawan harus mempunyai tekad untuk yakin, mampu mancari peluang dan berhasil dimasa depan. 
4. Tolerance for risk, ambiquity, and uncertainty, yaitu tahan terhadap resiko dan ketidakpastian. Wirausahawan harus belajar mampu mengelola resiko dan cara mentransfer resiko ke pihak lain seperti investor, konsumen, pemasok dan lain-lain.

5. Self confidence, yaitu percaya diri. Wirausahawan cenderung optimis terhadap apa yang dikerjakan untuk pencapaian tujuan.

6. Creativity and flexibility, yaitu berdaya cipta dan luwes. Seorang wirausahawan harus cepat dan fleksibel menghadapi perubahan permintaan. Untuk mencapai itu semua dibutuhkan kreativtas yang tinggi.

7. Desire for immadiate feedback, yaitu wirausahawan selalu menghendaki umpan balik dan ingin selalu mengetahui hasil dari apa yang dikerjakannya. Untuk memperbaiki hasil kerjanya, ia selalu menggunakan pengetahuan yang dimiliki dan belajar dari kegagalan.

8. High level of energy, yaitu memiliki semangat dan kerja keras yang tinggi untuk mewujudkan tujuannya.

9. Motivation to excel, yaitu memiliki dorongan untuk selalu unggul. Ia memiliki keinginan untuk lebih berhasil dalam mengerjakan apa yang dilakukannya. Motivasi ini muncul karena dari dalam diri (internal) dan jarang dari eksternal.

10. Orientation to the future, yaitu seorang wirausahawan harus berorientasi ke masa depan, dan tidak melihat ke belakang tanpa evaluasi yang jelas.

11. Willingness to learn from failure, yaitu selalu belajar dari kegagalan. Seorang wirausahawan harus yakin pada kemampuannya untuk berhasil, dan pantang menyerah jika terjadi kegalalan.

12. Leadership ability, yaitu kemampuan dalam kepemimpinan. Wirausaha yang ingin berhasil harus mampu memimpin dan memberikan pengaruh sebagai arahan untuk mencapai tujuan, ia harus mampu menjadi seorang mediator dan negotiator dari pada menjadi seorang diktator.

Menurut Sutanto (2002) seorang wirausahawan atau entrepreneur harus memiliki sikap mental individu yang berani menanggung risiko, berpikiran maju, berani berdiri di atas kaki sendiri. Sikap mental inilah yang akan membawa seorang pengusaha untuk dapat berkembang secara terus-menerus dalam jangka panjang. Selanjutnya menurut Suryana (2013:22), Ciri-ciri umum kewirausahaan dapat dilihat dari berbagai aspek kepribadian, seperti jiwa, watak, sikap, dan prilaku seseorang. Ciri-ciri yang meliputi enam komponen penting, yaitu: percaya diri, berorientasi pada hasil, berani mnegambil resiko, kepemimpinan, keorsinilitasan dan berorientasi pada masa depan.Ciri-ciri tersebut dapat dapat dilihat dari beberapa indicator sebagai berkut:Penuh percaya diri, indikatornya adalah penuh keyakinan, optimis, berkomitmen,disiplin, bertanggung jawab.Memiliki inisiatif, indikatornya adalah penuh energy, cekatan dalam bertindak, dan aktif.Memiliki motif berprstasi, indikatornya adalah berorentasi pada hasil dan wawasan kedepan.Memiliki jiwa kepemimpianan, indikatornya adalah berani tampil beda, dapat dipercaya,tangguh dalam bertindak.Berani mengambil resiko dengan penuh perhitungan, dan oleh karena itu menyukai tantangan.

\section{Teori Motivasi}

Suryana dan Bayu (2010:98) Motivasi merupakan proses psikologi yang mendasar, dan merupakan salah satu unsur yang dapat menjelaskan perilaku seseorang. Motivasi merupakan salah satu factor penentu dlam pencapaian tujuan. Motivasi berhubungan dengan dorongan atau kekuatan yang berada dalam diri manusia. Motivasi berada dalam diri manusia yang tidak terlihat dari luar. Motivasi menggerakkan manusia untuk menampilkan tingkah laku ke arah pencapaian suatu tujuan tertentu.

Menurut Ahmadi (2004), motivasi merupakan dorongan yang telah terikat pada suatu tujuan. Motivasi merupakan hubungan sistematik antara suatu respons atau himpunan respons dan keadaan dorongan tertentu.Menurut Siswanto dalam Purnama (2010:179) motivasi merupakan:Setiap perasaan atau kehendak dan keinginan yang amat mempengaruhi kemauan individu, sehingga individu tersebut didorong untuk berperilaku atau bertindakPengaruh kegiatan yang menimbulkan perilaku individu.Setiap tindakan atau kejadian yang menyebabkan berubahnya perilaku seseorang Proses dalam yang menentukan gerakan atau tingkah laku individu kepada tujuan (goals).

Kemudian John P. Campbell dkk (2002) menambahkan rincian dalam definisi tersebut dengan megemukakan bahwa motivasi mencakup di dalamnya arah atau tujuan tingkah laku, kekuatan respons, dan kegigihan tingkah laku. Di samping itu istilah itupun mencakup sejumlah konsep seperti dorongan (drive), kebutuhan (need), 
rangsangan (incentive), ganjaran (reward), penguatan (reinforcement), ketetapan tujuan (goal setting), harapan (expectancy), dan sebagainya.

Peran motivasi seseorang sangat penting dalam berwirausaha, karena motivasi dapat menentukan sejauh mana keberhasilan dapat diraih. Motivasi juga menggambarkan suatu keadaan yang dapat mempengaruhi berbagai aspek dari proses kewirausahaan. Hamalik (2004 : 161), mengungkapkan bahwa motivasi mendorong timbulnya kelakuan, dan mempengaruhi serta mengubah kelakuan. Jadi fungsi motivasi meliputi: a) Mendorong timbulnyakelakuan b) Motivasi berfungsi sebagai pengarah c) Motivasi berfungsi sebagai penggerak.

Selanjutnya menurut Winardi dalam (Amri 2010: 14) menyatakan bahwa faktor-faktor yang mempengaruhi motivasi antara lain :Kebutuhan pribadiTujuan-tujuan dan persepsi orang atau kelompok yang bersangkutan Dengan cara apa kebutuhan-kebutuhan tersebut akan ter-realisasi.

\section{Kerangka Berpikir dan Hipotesis}

Dalam menghadapi masalah pengangguran yang ada di Indonesia berbagai upaya telah dilakukan pemerintah baik secara langsung maupun tidak langsung. Secara langsung pemerintah mengeluarkan program-program pencaharian tenaga kerja, secara tidak langsung pemerintah melalui menteri pendidikan menginstruksikan agar pendidikan tinggi khususnya mempersiapkan lulusan yang siap kerja dan mampu membuka lapangan pekerjaan bagi orang lain melalui mata kuliah kewirausahaan.

Diharapkan dengan adanya mata kuliah kewirausahaan tersebut akan menumbuhkan minat mahasiswa yang ditunjukkan dari sikap dan motivasi dari mahasiswa tersebut. Mahasiswa dalam menjalankan proses berwirausaha dipengaruhi oleh sikap berwirausaha. Menurut Sarwono (2009:201) sikap (attitude) adalah istilah yang mencerminkan rasa senang, tidak senang, atau perasaan biasa-biasa saja (netral) dari seseorang terhadap sesuatu. Sesuatu itu bisa benda, kejadian, situasi, orang-orang atau kelompok. Selanjutnya menurut Suryana (2013:22), Ciri-ciri umum kewirausahaan dapat dilihat dari berbagai aspek kepribadian, seperti jiwa, watak, sikap, dan prilaku seseorang. Ciri-ciri yang meliputi enam komponen penting, yaitu: percaya diri, berorientasi pada hasil, berani mnegambil resiko, kepemimpinan, keorsinilitasan dan berorientasi pada masa depan. Mahasiswa dalam sikap berwirausaha haruslah memiliki ciri-ciri tersebut. Dengan memiliki ciri tersebut, mahasiswa dapat menjadi pengusaha yang mampu berdiri sendiri dan sukses.
Selain dipengaruhi oleh sikap wirausaha, yang memperngaruhi minat seseroang dalam berwirausaha adalah motivasi, karena motivasi yang akan memacu semangat siswa untuk terus menjalankan usaha sampai mencapai tujuannya. Peran motivasi seseorang sangat penting dalam berwirausaha, karena motivasi dapat menentukan sejauh mana keberhasilan dapat diraih. Motivasi juga menggambarkan suatu keadaan yang dapat mempengaruhi berbagai aspek dari proses kewirausahaan.

Berdasarkan uraian di atas, untuk memperjelas hubungan antara variabel, maka dikemukakan kerangka pemikiran seperti terlihat pada gambar berikut :

\section{Gambar 1. Kerangka Konseptual}

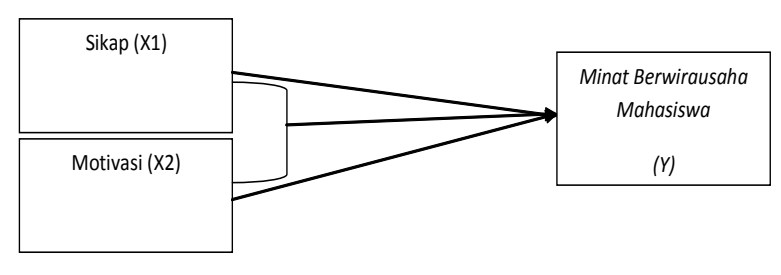

Dari bagan tersebut,adapun yang menjadi hipotesis dalam penelitian ini adalah :

1. Sikap berpengaruh positif dan signifikan terhadap minat berwirausaha mahasiswa Program Studi Ilmu Administrasi Bisnis FISIP Unka.

2. Motivasi berpengaruh positif dan signifikan terhadap minat berwirausaha mahasiswa Program Studi Ilmu Administrasi Bisnis FISIP Unka.

3. Sikap dan Motivasi secara bersama-sama berpengaruh positif dan signifikan terhadap minat berwirausaha mahasiswa Program Studi Ilmu Administrasi Bisnis FISIP Unka.

\section{Metode Penelitian}

Jenis penelitian ini berupa deskriptif kuantitatif yaitu penelitian yang mengukur kekuatan hubungan antar dua variabel atau lebih untuk menggambarkan sifat-sifat (karakteristik) dari objek penelitian yang dilakukan melalui pengumpulan dan analisis data. Populasi dalam penelitian ini adalah seluruh mahasiswa Program Studi Ilmu Administrasi Bisnis yang masih aktif kuliah hingga tahun 2019 yang berjumlah251 mahasiswa. Teknik pengambilan sampel yang akan digunakan oleh peneliti dalam penelitian ini adalah purposive sampling dengan menetapkan kriteria mahasiswa Ilmu Administrasi Bisnis minimal berada pada semester VI (enam) dan dalam status aktif kuliah dan telah mengambil mata kuliah 
Kewirausahaan. Berdasarkan kriteria-kriteria yang telah ditentukan tersebut, maka sampel yang digunakan di dalam penelitian ini berjumlah 61 responden.

Teknik analisis data yang digunakan yakni menggunakan analisis linear berganda dengan bantuan program SPSS versi 16. Sebelum dilakukan uji analisis data, peneliti terlebih dahulu melakukan uji validitas dan realibilitas.

\section{Hasil Penelitian dan Pembahasan Hasil Uji Validitas Dan Reliabilitas}

Hasil uji validitas data penelitian dapat dilihat pada tabel sebagai berikut :

Tabel 1. Hasil Pengujian Validitas

\begin{tabular}{|c|c|c|c|}
\hline Variabel/item & Nilai r Hitung & Nilai r Syarat & Hasil Uji \\
\hline \multicolumn{4}{|l|}{ Sikap (X1) } \\
\hline S1 & 0,685 & 0,30 & Valid \\
\hline S2 & 0,324 & 0,30 & Valid \\
\hline S3 & 0,671 & 0,30 & Valid \\
\hline S4 & 0,697 & 0,30 & Valid \\
\hline S5 & 0,600 & 0,30 & Valid \\
\hline S6 & 0,466 & 0,30 & Valid \\
\hline S7 & 0,460 & 0,30 & Valid \\
\hline S8 & 0,673 & 0,30 & Valid \\
\hline S9 & 0,601 & 0,30 & Valid \\
\hline S10 & 0,492 & 0,30 & Valid \\
\hline \multicolumn{4}{|l|}{ Motivasi (X2) } \\
\hline MO1 & 0,711 & 0,30 & Valid \\
\hline $\mathrm{MO} 2$ & 0,663 & 0,30 & Valid \\
\hline MO3 & 0,698 & 0,30 & Valid \\
\hline MO4 & 0,558 & 0,30 & Valid \\
\hline MO5 & 0,672 & 0,30 & Valid \\
\hline MO6 & 0,512 & 0,30 & Valid \\
\hline MO7 & 0,560 & 0,30 & Valid \\
\hline MO8 & 0,625 & 0,30 & Valid \\
\hline MO9 & 0,534 & 0,30 & Valid \\
\hline MO10 & 0,694 & 0,30 & Valid \\
\hline \multicolumn{4}{|l|}{ Minat (Y) } \\
\hline MI1 & 0,613 & 0,30 & Valid \\
\hline MI2 & 0,588 & 0,30 & Valid \\
\hline MI3 & 0,772 & 0,30 & Valid \\
\hline MI4 & 0,679 & 0,30 & Valid \\
\hline MI5 & 0,702 & 0,30 & Valid \\
\hline MI6 & 0,682 & 0,30 & Valid \\
\hline MI7 & 0,607 & 0,30 & Valid \\
\hline MI8 & 0,621 & 0,30 & Valid \\
\hline MI9 & 0,129 & 0,30 & Valid \\
\hline MI10 & 0,682 & 0,30 & Valid \\
\hline
\end{tabular}

Sumber: Data Primer, Diolah, 2019

Tabel 1 tersebut menunjukan nilai $\mathrm{r}$ hitung masing-masing item pertanyaan/pernyataan pada variabel penelitian lebih besar dari $r$ yang dipersyaratkan. Sehingga dapat disimpulkan bahwa seluruh item pertanyaan dalam instrumen penelitian ini dapat dinyatakan valid dan layak jika digunakan untuk mengukur Pengaruh Sikap dan motivasi terhadap minat berwirausahaMahasiswa Program Studi Ilmu Administrasi Bisnis FISIP Unka. 
Adapun hasil olahan data mengenai uji reliabilitas data instrumen penelitian dapat

dirangkum pada tabel 2 sebagai berikut:

Tabel 2. Hasil Uji Reliabilitas

\begin{tabular}{|l|c|c|c|}
\hline \multicolumn{1}{|c|}{ Variabel } & Cronbach's Alpha & $\begin{array}{c}\text { Cronbach's Alpha } \\
\text { Standar }\end{array}$ & Hasil Uji \\
\hline Sikap (X1) & 0,860 & 0,60 & Reliabel \\
\hline Motivasi (X2) & 0,886 & 0,60 & Reliabel \\
\hline Minat Mahasiswa (Y) & 0,880 & 0,60 & Reliabel \\
\hline
\end{tabular}

Sumber: Data Primer, Diolah, 2018

Berdasarkan hasil pengujian reliabilitas yang terdapat pada tabel 2 tersebut, maka dapat disimpulkan bahwa seluruh item dalam instrumen penelitian dinyatakan reliabel dan konsisten jika digunakan untuk mengukur Pengaruh Sikap dan motivasi terhadap minat berwirausahaMahasiswa
Program Studi Ilmu Administrasi Bisnis FISIP Unka.

\section{Uji Analisis Linier Regresi Berganda}

Selanjutnya adalah hasil uji analisis linier regresi berganda yang terlihat pada tabel 3 sebagai berikut:

Tabel 3. Hasil Uji Regresi Linier Berganda

\section{Coefficients $^{\mathrm{a}}$}

\begin{tabular}{|c|c|c|c|c|c|}
\hline \multirow[b]{2}{*}{ Model } & \multicolumn{2}{|c|}{ Unstandardized Coefficients } & \multirow{2}{*}{$\begin{array}{c}\text { Standardized } \\
\text { Coefficients }\end{array}$} & \multirow[b]{2}{*}{$\mathrm{t}$} & \multirow[b]{2}{*}{ Sig. } \\
\hline & B & Std. Error & & & \\
\hline 1 (Constant) & 3.813 & 6.022 & & .633 & .529 \\
\hline SIKAP & .263 & .167 & .205 & 1.575 & .121 \\
\hline MOTIVASI & .596 & .157 & .494 & 3.799 & .000 \\
\hline
\end{tabular}

a. Dependent Variable: MINAT

MAHASISWA

Sumber: Data Primer, Diolah 2019

Tabel 3 tersebut dapat dijelaskan sebagai berikut:

1. Berdasarkan hasil pengolahan data pada tabel 4.10 diperoleh persamaan regresi linier berganda yaitu $\mathrm{Y}=3,813+0,263 \mathrm{X} 1+0,596$ $\mathrm{X} 2$

2. Konstanta (a) $=3,813$ berarti bahwa minat mahasiswa akan konstan sebesar 3,813 satuan jika tidak ada pengaruh dari sikap (X1), dan motivasi (X2).

3. Minat mahasiswa akan meningkat sebesar 0,263 satuan untuk setiap tambahan satu satuan sikap (X1), Jadi apabila sikap mengalami peningkatan 1 satuan, maka minat mahasiswa akan meningkat sebesar 0,263 satuan dengan asumsi variabel yang lainnya dianggap konstan.
4. Minat mahasiswa akan meningkat sebesar 0,596 satuan untuk setiap tambahan satu satuan motivasi (X2). Jadi apabila motivasi mengalami peningkatan 1 satuan, maka minat mahasiswa akan meningkat sebesar 0,596 satuan dengan asumsi variabel yang lainnya dianggap konstan.

\section{Uji Korelasi}

Uji korelasi dilakukan untuk mengetahui seberapa besar nilai kekuatan hubungan antara variabel penelitian. Adapun hasil pengujian korelaasi variabel penelitian dalam penelitian ini dapat dilihat pada tabel berikut: 
Tabel 4 Hasil Uji Korelasi

Correlations

\begin{tabular}{|ll|r|r|r|}
\hline & & & & \multicolumn{2}{|c|}{ MINAT } \\
\hline SIKAP & Pearson Correlation & 1 & $.634^{* *}$ & \multicolumn{2}{|c|}{ MAHASISWA } \\
& Sig. (2-tailed) & $.518^{* * *}$ \\
& $\mathrm{~N}$ & 61 & .000 & .000 \\
& Pearson Correlation & $.634^{* *}$ & 61 & 61 \\
\hline MOTIVASI & Sig. (2-tailed) & .000 & 1 & $.624^{* * *}$ \\
& $\mathrm{~N}$ & 61 & 61 & .000 \\
& Pearson Correlation & $.518^{* *}$ & $.624^{* *}$ & 61 \\
\hline MINAT & Sig. (2-tailed) & .000 & .000 & 61 \\
\hline
\end{tabular}

**. Correlation is significant at the 0.01 level (2-tailed).

Sumber: data primer, diolah tahun 2019.

Berdasarkan output hasil uji korelasi pada tabel 4 tersebut terlihat bahwa antara variabel sikap (X1) dengan variabel minat mahasiwa (Y) memiliki nilai koefisien korelasi sebesar 0,518 dengan tingkat signifikansi sebesar 0,000 , sehingga dapat disimpulkan bahwa variabel sikap memiliki hubungan yang dengan variabel minat mahasiswa.

Selanjutnya variabel motivasi (X2) dengan variabel minat mahasiswa (Y) memiliki nilai koefisien korelasi sebesar 0,624 dengan tingkat signifikansi sebesar 0,000, sehingga maka dapat disimpulkan bahwa variabel motivasi memiliki hubungan dengan variabel minat mahasiswa.

\section{Pengujian Hipotesis}

\section{Uji t}

Uji t digunakan untuk menguji secara parsial masing-masing variabel. Hasil uji t dapat dilihat pada tabel coefficient pada kolom sig (significance). Jika probabilitas nilai t signifikan $<0,05$ maka dapat dikatakan bahwa terdapat pengaruh antara variabel bebas terhadap variabel terikat. Hasil uji t dapat dilihat pada tabel 4.12 sebagai berikut:

Tabel 5 Nilai Koefisien t Variabel Penelitian

\begin{tabular}{|l|c|c|}
\hline \multicolumn{1}{|c|}{ Variabel } & $\mathrm{t}$ & Sig. \\
\hline (Constant) & 0,633 & 0,529 \\
\hline Sikap & 1,575 & 0,121 \\
\hline Motivasi & 3,799 & 0,000 \\
\hline
\end{tabular}

Dependent Variable: Minat Mahasiswa

Sumber: data primer, diolah 2019
Berdasarkan hasil uji tersebut terihat bahwa besarnya koefisien thitung untuk variabel sikap adalah 1,575 dengan tingkat signifikansi 0,121 yang lebih besar dari 0,05 , sehingga dapat disimpulkan bahwa H0 diterima dan Ha ditolak, sehingga hipotesis pertama dalam penelitian ini yakni sikap tidak berpengaruh signifikan terhada minat berwirausaha mahasiswa Prodi Ilmu Administrasi Bisnis Fisip Unka.

Selanjutnya besarnya koefisien t hitung untuk variabel motivasi adalah 3,799 dengan tingkat signifikansi 0,000 yang lebih kurang dari 0,05 , sehingga dapat disimpulkan bahwa hipotesis kedua dalam penelitian ini motivasi berpengaruh signifikan terhadap minat berwirausaha mahasiswa Prodi Ilmu Administrasi Bisnis Fisip Unka.

Hasil uji simultan atau uji $\mathrm{F}$ pada penelitian ini adalah untuk mengetahui apakah semua variabel bebas yang dimasukkan ke dalam model penelitian mempunyai pengaruh secara bersama-sama terhadap variabel terikat. Hasil uji F dapat dilihat pada tabel Anova output dari program SPSS. Selanjutnya hasil uji $\mathrm{F}$ tersebut dibandingkan dengan $\mathrm{F}$ tabel. Jika $\mathrm{F}$ hitung $>$ dari $\mathrm{F}$ tabel maka hipotesis diterima dan sebaliknya jika $\mathrm{F}$ hitung $<$ dari F Tabel maka hipotesis ditolak.

Adapun hasil uji F (simultan) pada penelitian ini dapat dilihat pada tabel berikut: 
Tabel 6 Hasil Uji F (Simultan)

\begin{tabular}{|c|c|c|c|c|c|c|}
\hline \multicolumn{7}{|c|}{ ANOVA $^{b}$} \\
\hline & & Sum of Squares & $\mathrm{df}$ & Mean Square & $\mathrm{F}$ & Sig. \\
\hline \multirow[t]{3}{*}{1} & Regression & 822.876 & 2 & 411.438 & 20.483 & $.000^{\mathrm{a}}$ \\
\hline & Residual & 1165.058 & 58 & 20.087 & & \\
\hline & Total & 1987.934 & 60 & & & \\
\hline
\end{tabular}

a. Predictors: (Constant), MOTIVASI, SIKAP

b. Dependent Variable: MINAT MAHASISWA

Sumber: data primer, diolah tahun 2019.

Berdasarkan Tabel 6, nilai F hitung sebesar 20,483. Sedangkan F tabel $(a ́=0.05 ;$ df regresi $=$ $2:$ df residual $=58$ ) adalah sebesar 3,16. Karena F hitung $>$ F tabel yaitu 20,483 > 3,16 maka model analisis regresi adalah signifikan. Hal ini berarti H0 ditolak dan Ha diterima sehingga dapat disimpulkan bahwa variabel sikap (X1) dan motivasi (X2) berpengaruh secara simultan terhadap variabel minat mahasiswa (Y).

\section{Koefisien Determinasi}

Koefisien determinasi digunakan untuk mengetahui besar kontribusi variabel sikap (X1) dan motivasi (X2) terhadapvariabel minat mahasiswa (Y). Langkah yang dapat digunakan yaitu dengan melihat nilai $R$ Square pada tabel model summary sebagai berikut:

Tabel 7 Koefesien Determinasi

\section{Model Summary ${ }^{b}$}

\begin{tabular}{|l|r|r|r|r|}
\hline Model & & & & \\
R & R Square & Adjusted R Square & \multicolumn{2}{|c|}{$\begin{array}{c}\text { Std. Error of the } \\
\text { Estimate }\end{array}$} \\
\hline 1 & $.643^{\mathrm{a}}$ & .414 & .394 & 4.482 \\
\hline
\end{tabular}

a. Predictors: (Constant), MOTIVASI, SIKAP

b. Dependent Variable: MINAT MAHASISWA

Sumber: Data primer, diolah tahun 2019

Koefisien determinasi digunakan untuk menghitung besarnya pengaruh atau kontribusi variabel bebas terhadap variabel terikat. Dari analisis pada Tabel 7 diperoleh hasil $R$ Square (koefisien determinasi) sebesar 0,414 yang menunjukkan bahwa 41,4\% variabel minat mahasiswa (Y) akan dipengaruhi oleh variabel bebasnya, yaitu sikap (X1) dan motivasi (X2), sedangkan sisanya $58,6 \%$ variabel minat mahasiswa akan dipengaruhi oleh variabel-variabel yang lain yang tidak dibahas dalam penelitian ini.

\section{Kesimpulan}

Berdasarkan hasil penelitian yang telah dilakukan, maka diperolehkesimpulan sebagai berikut:

1. Sikap tidak berpengaruh signifikan terhadap minat berwirausaha mahasiswa Prodi Ilmu Administrasi Bisnis Fisip Unka. Artinya mahasiswa belum mampu untuk membuat atau menciptakan suatu lapangan pekerjaan. Hal ini dikarenakan kondisi mahasiswa yang dituntut untuk menyelesaikan studinya, terbatasnya modal yang dimiliki, sumber daya dan kondisi yang masih bergantung kepada orang tua.

2. Motivasi berpengaruh signifikan terhadap minat berwirausaha mahasiswa Prodi Ilmu Administrasi Bisnis Fisip Unka. Motivasi berwirausaha merupakan salah satu hal yang melatar belakangi seseorang untuk melakukan sesuatu untuk mencapai tujuan tertentu. Motivasi berwirausaha dapat muncul dalam diri seseorang karena adanya dorongan untuk mencapai kesuksesan dalam bidang kewirausahaan. Motivasi berwirausaha yang tinggi akan memberikan dampak yang tinggi pula terhadap minat berwirausaha 


\section{Saran}

Berdasarkan hasil penelitian dan kesimpulan tersebut maka terdapat beberapa hal yang dapat disarankan yaitu:

1. Diharapkan agar pihak prodi lebih memperhatikan mahasiswa tingkat akhir semester supaya mahasiswa lebih menumbuhkan sikap yang baik, motivasi yang tinggi untuk menumbuhkan minat berwirausaha dengan cara memberikan kesempatan kepada mahasiswa untuk mengikuti pelatihan tentang menumbuhkan jiwa berwirausaha dan bekerja sama dengan lembaga terkait.

2. Diharapkan agar mahasiswa dapat terus belajar melihat dan meraih peluang berwirausaha. Berani dalam mengambil keputusan dan tidak takut dengan tantangan, dengan cara selalu berpikir optimis, dinamis dan kreatif.

\section{Daftar Pustaka}

Ahmadi, Abu. 2004. Psikologi Pendidikan. Jakarta: Rineka Cipta

Djaali. 2008. Psikologi Pendidikan. Jakarta: Bumi Aksara.

Gitosardjono, Sukamdani Sahid. 2013. Wirausaha Berbasis Islam \& Kebudayaan. Jakarta: Pustaka Bisnis Indonesia.

Hamalik, Oemar. 2004. Psikologi Belajar dan Mengajar. Bandung: Sinar Baru Algensindo.

John P Campbell. 2002. Modeling the Performance Prediction Problem in Industrial and Organizational Psychology, Handbook of Industrial and Psychology, Volume 1, ed. Marvin D. Dunnette and Leaette M. Hough. Mumbai: Jaico Publishing House.
Kristsada, A. D. 2010. Peningkatan Minat Membaca Pelajaran Bahasa Indonesia melalui Layanan Bimbingan Belajar dengan Teknik Diskusi Kelompok pada Siswa Kelas XI AP/AK SMK MARSUDI LUHUR 1. Yogyakarta. Skripsi.FIPUNY.

Sabri, Ahmad. 2007. Strategi Belajar Mengajar Micro Teaching. Ciputat: Quantum Teaching.

Santoso, Singgih. 2009. Business Forecasting: Metode Peramalan Bisnis Masa Kini Dengan Minitab \& SPSS. Jakarta: Elex Media Komputindo

Sarwono, Sarlito W. 2009. Pengantar Psikologi Umum. Depok: Rajawali Pers.

Slameto. 2003. Belajar dan Faktor-faktor yang Mempengaruhinya. Jakarta: Rineka Cipta.

Subandono, Aris. 2007. PengaruhLife Skill Diklat Kimia Produktif Dan Prestasi Belajar Diklat Kewirausahaan Terhadap Minat Berwirausaha Pada Siswa SMK Kimia Industri Theresiana Semarang [Skripsi]. Semarang: Universitas Negeri Semarang.

Suryana, Yuyus dan Kartib Bayu. 2010. Kewirausahaan Pendekatan Karakteristrik Wirausaha Sukses. Jakarta: Kencana

Suryana. 2013. Ekonomi Keatif, Ekonomi Baru: Mengubah Ide dan Menciptakan Peluang. Jakarta: Salemba Empat

Suryana. 2014. Kewirausahaan, Edisi IV.Jakarta: Salemba Empat

Sutanto, Adi. 2002. Kewiraswataan. Jakarta: Ghalia Indonesia.

Zimmerer, Thomas W Dkk. 2008. Kewirausahaan Dan Manajemen Usaha Kecil Edisi 5 Buku 1. Jakarta: Salemba Empat. 